Irena Selišnik

\title{
Smilja Amon, Karmen Erjavec: Slovensko časopisno izročilo 1 : od začetka do 1918
}

\author{
Ljubljana: Fakulteta za družbene vede, Založba FDV, knjižna zbirka Media 2011, \\ 199 strani
}

Knjiga Slovensko časopisno izročilo 1 želi predstaviti zgodovino časopisja na Slovenskem, pri čemer sta si avtorici za cilj zastavili predvsem predstavitev tiskanih medijev kot nosilcev idejnih tokov v posameznih zgodovinskih obdobjih. Tekst tako podaja pregled vseh revij in časopisov, ki so v slovenskem prostoru izhajali do konca prve svetovne vojne. Kronološki pregled sprva poseže v začetke »slovenskega časopisnega izročila«, ki naj bi sodili v čas reformacije, s posameznimi posegi v srednji vek, se nadaljuje s predstavitvijo nemških časopisov, ki so izhajali v 18. stoletju, ter se nato osredotoči na bogato raznovrstnost časopisja v 19. stoletju in na začetku 20. stoletja. Kronološki pregled časopisov je strukturiran okrog glavnih političnih konfliktov, ki so zaznamovali zgodovino na Slovenskem. Tako se poleg ločitve na nemško in slovensko časopisje uveljavi tudi delitev na liberalno, katoliško in socialdemokratsko časopisje. Ta pregled dopolnjuje pregled časopisov, ki so izhajali ne le v osrednji Kranjski, pač pa tudi v drugih deželah, kjer so živeli Slovenci.

$\mathrm{V}$ uvodu avtorici zapišeta nekatere ugotovitve, ki naj bi povzemale njuno sintezo. Trdita, da je »slovensko časopisje potrebno umestiti na obrobje državno družbene pozornosti« v monarhiji (str. 6), da je bil slovenski časopis provincialen in da so oblike novinarskega sporočanja, ki sta jih uporabljala vodilna dnevnika na Slovenskem, Slovenec in Slovenski narod, komaj primerljive z zahodnimi, s čimer je verjetno mišljena zahodna Evropa. Tako ostra ocena takratnih slovenskih časopisov je po vsej verjetnosti malo pretirana, saj bi bilo treba slovensko časopisje primerjati v kontekstu srednje Evrope in Avstro-Ogrske monarhije. Avtorici tudi zapišeta, da se je slovensko časopisje razvijalo v okvirih, ki so jih narekovale tuje oblasti, ter da je o njegovem razvoju in svobodi odločala oblast, na katero slovenska javnost ni imela večjega vpliva. Ta deterministični pogled najbrž spregleda in zanemari moč pobude, ki jo je nosila slovenska javnost, pa tudi množico prošenj in vlog za ustanovitev časopisov in revij, ki so ostale $\mathrm{v}$ arhivih in iz njih nikoli ni nastala nova revija ali časopis - avtorici izjemoma omenjata nekatere pobude socialdemokratov. Zdi se, da njuna sinteza zanemari voluntaristične vidike zgodovine. Med drugim neprijetno 
zbode v oči trditev, da lahko že v 8. oziroma 9. stoletju govorimo o slovenskih družbenih tokovih.

S podobnimi trditvami se namreč začne tudi naslednje poglavje knjige Obdobje prehodništva na Slovenskem. Slovensko zapisano besedo naj bi tako našli že v zgodnjem srednjem veku, nasploh pa naj bi slovenska skupnost pastirjev, lovcev, kmetov in obrtnikov govorila v svojem jeziku že veliko prej, preden so bila besedila (v slovenščini) sploh zapisana. Te trditve avtorici črpata iz knjige I. Grdine, posredno pa omenjata tudi knjigo Milka Kosa, ki je bila objavljena daljnega leta 1955. Tovrstni argumenti so predmet številnih polemičnih diskusij, ki so dodobra zaznamovale zgodovinopisje. S tovrstnim, lahko bi rekli metodološkim nacionalizmom, ki je bil v uporabi večino 20 . stoletja, sta zanemarili sodobne zgodovinske študije o tej problematiki (Peter Štih in Vasko Simoniti, Jernej Kosi). Sodoben slovenski narod je produkt 19. stoletja, besede Slovenec v zgodnjem srednjem veku ne srečamo. V Trubarjevem času res srečamo uporabo besede Slovenci, toda ta je takrat imela drugačen semantični pomen. Prav zato je treba biti pri uporabi besed, kot sta Slovenci in slovenščina, zelo previden in se zavedati, da sta lahko jezik in etnična skupnost dve povsem različni kategoriji. $\mathrm{V}$ tem poglavju S. Amon in K. Erjavec pišeta o prvih mejnikih razvoja slovenskega časopisnega izročila ter omenjata prihod prvih časopisov iz nemških dežel preko poštnih povezav in Trubarjevo publicistično dejavnost.

Sledi poglavje o časopisju v nemškem jeziku, v katerem so pregledno nanizani nemški časopisi, ki so izhajali na Slovenskem. Prvi med njimi je seveda predstavljen Laibacher Zeitung, nemški časopis, ki je izhajal najdlje, nato pa sledi prikaz njegovih prilog. Zanemarjeno ni tudi drugo časopisje $\mathrm{v}$ nemškem jeziku, ki je izhajalo na Kranjskem, Štajerskem in Koroškem. V pregledu so predstavljeni uredniki, struktura (notranje in zunanje politične vesti, feljtoni) ter osnovni cilj in usmeritev časopisov. Poleg "nemškutarskih časopisov« - avtorici to oznako morda občasno uporabljata preveč prostodušno - so obstajali tudi časopisi v nemškem jeziku, ki so prav tako širili slovenske ideje in katerim je $\mathrm{v}$ knjigi prav tako odmerjen primeren prostor.

Naslednje poglavje Obrtniška stopnja razvoja, ki ga piski kronološko umeščata v čas od konca 18. stoletja do srede 19. stoletja in ki se nekoliko prekriva s prejšnjim poglavjem, se začne s krajšim zgodovinskim pregledom družbenih in političnih razmer na Slovenskem. V poglavju predstavita prvi časopis v slovenskem jeziku Lublanske novice. Gradivo za predstavitev Novic vsaj deloma temelji na virih, ki so uporabljeni za podkrepitev analize, mestoma pa tudi le kot kuriozitete, ki poživijo slog pisanja. To poglavje se zaradi uporabe virov razlikuje od drugih poglavij, kjer časopisnih citatov praviloma ne srečamo. $\mathrm{V}$ obdobje obrtniškega razvoja je umeščeno tudi mednoviško obdobje, obdobje Ilirskih provinc in Metternichovega absolutizma. Predstavljeni so 
Télégraphe Officiel des Provinces Illyriennes, primež cenzure v obdobju pred letom 1848 in Kranjska čbelica. V tem poglavju avtorici zapišeta tudi nekoliko sporno trditev, da se je slovenska politična zavest oblikovala šele po volitvah 1867 (str. 66) - večina zgodovinarjev bi raje navedla letnico 1848 .

Monografija se zaključi z obsežnim poglavjem Industrijska stopnja razvoja, v katerem so kronološko umeščeni vsi časopisi od leta 1843 do konca prve svetovne vojne. Poglavje se tudi tokrat začne $\mathrm{z}$ orisom splošnih zgodovinskih razmer, avtorici tako politične dogodke in razmere v štiridesetih letih 19. stoletja povzemata po članku Dragotina Lončarja o času Janeza Bleiweisa, ki je izšel pred več kot stoletjem, leta 1909. Tako se sploh ne čudimo, ko v tekstu preberemo trditve kot »meščani slovenskih mest so bili zaradi številnih vzrokov [...] v veliki večini nezainteresirani za slovenski narodni program « (str. 72) in da je večinsko prebivalstvo na vasi ohranjalo zavest o pripadnosti slovenski narodnosti (prav tam). Toda prav meščani so kot intelektualci, skupaj z duhovniki, tvorili elito in bili tako zaslužni za slovenski narodni preporod. Avtorici nato predstavljata Kmetijske in rokodelske novice ter njihov pomen za razvoj slovenske narodne zavesti in časopisja na Slovenskem. Posebej je obravnavana vloga Kmetijskih in rokodelskih novic $\mathrm{v}$ revolucionarnem letu 1848. Novicam se $\mathrm{v}$ tem letu pridruži še cela vrsta drugih časopisov: Slovenija, Ljubljanski časnik, Pravi Slovenec, Vedež, Slovenski cerkveni časopis, Celjske slovenske novine in nekoliko kasneje še Slavljanski rodoljub, Slovenska čbela in Jadranski Slavjan. Medtem ko sta Slovenija in Ljubljanski časnik predstavljena tudi s posameznimi citati iz njunih člankov, za ostale to ne velja. Citati želijo prispevati k razumevanju političnega programa, nekateri pasusi, npr. o Judih, pa zgolj razkrivajo del socialne zgodovine in ne sodijo v tovrstni pregled.

O obdobju Bachovega absolutizma spregovori eno izmed podpoglavij, ki je sicer umeščeno v Časopisje marčne revolucije. Bolj kot o časopisju spregovori o političnih razmerah pred ustavno dobo in $\mathrm{v}$ času ustavne dobe, $s$ čimer nadaljuje tudi naslednje podpoglavje Mariborski politični program. Sledi predstavitev Slovenca in časnika Naprej, nato pa še humorističnih časopisov v ustavnem obdobju, kjer med literaturo zagotovo pogrešamo tekste Damirja Globočnika. To podpoglavje zaključi tržaško in goriško časopisje.

Knjiga se nato počasi prevesi v zadnjo tretjino, ki se začne s poglavjem Slovensko liberalno časopisje s posebnimi podpoglavji Slovenski narod, Drugo liberalno časopisje in Žensko liberalno časopisje ter Časopisje liberalnih mladinov. Tudi v tem delu se pri opisu političnih razmer ponekod pojavljajo pretirane oznake kot »prva velika izdaja slovenskega narodnega interesa «, ta naj bi podrazumevala podporo liberalcev Nemški stranki (str. 129). Trditev, da so se od Slovenskega naroda zaradi njegove nedosledne politične usmerjenosti odvrnili predvsem izobraženci, mladina in kmetje, je prav tako 
vsaj rahlo sporna. Te ugotovitve bi morale biti plod analize Slovenskega naroda in arhivskega gradiva, ki v tej sintezi tako ali tako manjka, ne pa le povzemanja ugotovitev, ki naj bi veljale na splošno za liberalni politični tabor. Sledita še predstavitvi katoliškega časopisja, na čelu s Slovencem, vodilnim časnikom slovenskega političnega katolicizma, ter drugimi revijami in časopisi (Domoljub, Bogoljub, Učiteljski tovariš, Dolenjske novice, Mir, Novine za Vogerske Slovence, Rimski katolik, Katoliški obzornik, Časnik, Kres, Dom in svet). Posebej je obravnavano krščanskosocialistično (ustreznejši bi bil izraz krščanskosocialno) gibanje in njegovo časopisje. Knjigo zaključi predstavitev socialdemokratskega političnega tabora in njegovega časopisja. Tudi v tem delu lahko zasledimo veliko nedoslednosti; naj omenimo popolnoma nekritično objavo nekaterih citatov brez komentarja, npr. »Liberalci in klerikalci so krivi za socialno bedo in visoko smrtnost na Slovenskem: »Nikjer v Avstriji ni gospodarstvo tako nerazvito, zdravstvo tako zanemarjeno in umrljivost tako visoka « (str. 178). Spregledana je recimo tudi Alojzija Štebi, ki je sicer omenjena le kot urednica Ženskega lista in Demokracije, ne pa tudi Zarje, Delavca, Tobačnega delavca in Naprej.

Če povzamem, knjiga je sicer dober pregled tega, kateri časopisi so izhajali $\mathrm{v}$ določenem obdobju, vendar nič več kot to. Monografija ignorira sodobne ugotovitve zgodovinske stroke, poleg tega pa je tudi nekoliko nedosledno strukturirana, nekateri časopisi so predstavljeni kot podpoglavja, drugi ne. Humoristično časopisje v ustavnem obdobju bi si zaslužilo posebno podpoglavje. Žensko časopisje je sicer obravnavano $\mathrm{v}$ posebnem podpoglavju, ki pa ni navedeno v kazalu, medtem ko recimo učiteljski časopisi tega prostora niso dobili. Knjiga tako ne podaja novih ugotovitev o primerjavi števila izvodov časopisov (statistična poročila glede na četrtletje so dosegljiva $\mathrm{v}$ arhivskem gradivu), izgradnji bralnih javnosti ter pojavu profesionalnih novinarjev in novinark ali primerjave mreže dopisnikov - ti še vedno ostajajo potisnjeni $\mathrm{v}$ anonimnost, kot tudi številni uredniki (npr. Miroslav Malovrh), ki sta jih avtorici spregledali. 